\title{
Inter- and intraspecific variability in the chemical composition of the mineral phase of cements from several tube-building polychaetes ${ }^{\text {is }}$
}

\section{Variabilité inter- et intraspécifique de la composition chimique de la phase minérale des ciments utilisés dans la construction du tube de plusieurs polychètes bioconstructeurs}

\author{
Jérôme Fournier ${ }^{\mathrm{a}, *}$, Samuel Etienne ${ }^{\mathrm{b}}$, Jean-Benoît Le Cam ${ }^{\mathrm{c}}$ \\ ${ }^{a}$ CNRS-UMR 7208 BOREA, CRESCO, Muséum national d'histoire naturelle, 38, rue du Port Blanc, 35801 Dinard cedex, France \\ ${ }^{\mathrm{b}}$ Université de la Polynésie Française, UMR 6042 GEOLAB, BP 6570, 98702 Faa'a, Tahiti, French Polynesia \\ ${ }^{\mathrm{c}}$ Institut français de mécanique avancée, LaMI, CNRS-EA 3867-FR TIMS 2856, BP 265, 63175 Aubière cedex, France
}

\begin{abstract}
Several species of marine polychaetes reside in individual protective tubes. These tubes may be agglomerated in patches of varied sizes with very high densities, or form massive reef-like mounds which can be stretch over several kilometers. These polychaetes can thus be considered as the most important building organisms after corals in coastal environments. We especially focused on several species belonging to the families of Sabellariidae, Terrebeliidae and Pectinariidae. Tubes grains are glued together with biomineralized cement secreted from a building organ connected to specialized glands. Different methods of micro-analysis were used to analyze the biomineral components of these cements for four varyingly gregarious tube-building polychaetes: Lanice conchilega, Pectinaria koreni, Sabellaria alveolata and Phragmatopoma caudata. The aim of this study is to describe and compare the inter- and the intraspecific variability in the main biomineral components of cement at local, regional and continental scales. Scanning Electron Microscopy confirms an identical structure of the cement within species of Sabellariidae in Europe and America. Electron Probe Micro-Analysis (EPMA) confirms the presence of calcium, phosphorus, and magnesium plus traces of manganese in all cements, with varying concentrations of these elements at different locations for the same species or for different species at the same location. Finally, our dataset is compared with previous studies from literature.
\end{abstract}

Keywords: Biogeomorphology; Reefs; Polychaetes; Tube-worms; Cement; Micro-analysis

\section{Résumé}

Plusieurs espèces de polychètes marins vivent isolées dans des tubes protecteurs. Ces bioconstructions peuvent être non jointives, mais réparties sur de grands espaces, et pouvant atteindre de très fortes densités individuelles; d'autres construisent des formations récifales massives étendues parfois sur plusieurs kilomètres carrés. Ces polychètes peuvent ainsi être considérés comme les plus importants organismes bioconstructeurs de la zone littorale après les coraux hermatypiques. Les tubes des Sabellariidae, des Terrebeliidae et des Pectinariidae, par exemple, sont élaborés à partir de grains de sables et de fragments de coquilles d'une taille et d'une forme bien particulières, adaptées à l'organe préhensile du ver constructeur. L'organisation des clastes dans les parois des tubes est variable : celle des Sabellariidae ressemble à l'agencement des tuiles d'un toit alors que les fragments de coquilles utilisés par les Terrebeliidae sont assemblés de manière aléatoire. Les grains sont collés à l'aide d'un ciment biominéralisé secrété par un organe spécialisé connecté aux glandes cémentaires. Différentes méthodes de microanalyse ont été utilisées pour analyser la composante biominérale de ces ciments pour quatre espèces de polychètes tubicoles : Lanice conchilega, Pectinaria koreni, Sabellaria alveolata et Phragmatopoma caudata. L'objectif de cette étude est de décrire et de mesurer la variabilité inter- et intraspécifique des principaux éléments du ciment aux échelles locale, régionale et continentale. La Microscopie Électronique à Balayage montre que la structure du ciment entre les espèces de Sabellariidae en Europe et en Amérique est identique. L'analyse par micro-sonde électronique (EPMA) confirme la présence de calcium, de phosphore et de magnésium, avec des traces de manganèse dans tous les ciments. La teneur de ces

\footnotetext{
is Corresponding editor: Gilles Escarguel.

* Correspondant author.

E-mail address: fournier@mnhn.fr (J. Fournier).
} 
éléments varie selon l'environnement pour la même espèce et selon les espèces dans un même environnement. Une comparaison des données acquises avec celles de la littérature est présentée.

Mots clés : Biogéomorphologie ; Récifs ; Polychètes ; Vers tubicoles ; Ciments ; Micro-analyse

\section{Introduction}

Several species of marine polychaetes reside within selfcreated protective tubes. Some of these worms construct isolated tubes in variously large patches with very high tube densities (Rabaut et al., 2008). Others form massive reef-like mounds which can reach several kilometers in length (Caline et al., 1988; Kirtley, 1994; Naylor and Viles, 2000). These species of polychaetes can be considered as the most important building organisms after corals in coastal environments. We especially focused on several species belonging to the families of Sabellariidae, Terrebeliidae and Pectinariidae. Their tubes are made from sand clasts and bits of calcareous shell fragments of a given size and shape gathered in the water column. The organisation of clasts in the tube walls of Sabellariidae resembles roof tiles whereas those of Terrebeliidae are randomly attached. Grains are glued with a biomineralized cement secreted from a building organ connected to specialized glands (Vovelle, 1965; Truchet and Vovelle, 1977; Vovelle and Grasset, 1990).

For biogeomorphologists, the study of these species of marine worms is of primary importance because annelid reefs and beds that do not produce carbonate may however concentrate carbonate-rich sediments (Fournier et al., 2005, $2007 \mathrm{a}, \mathrm{b})$. These colonies actively control the texture and the distribution of intertidal sands because of their ability to trap and selectively concentrate particles of specific mineralogy and grain-size. These bioconstructions provide a spectacular example of modern carbonate-rich reefs or beds living under temperate and tropical climates.

Pectinaria (=Lagis) koreni (Malmgren, 1866) [Pectinariidae] is an infaunal polychaete widely spread in the Northern European sandflats (Fig. 1(a)). This intertidal species displays a clear preference for fine sediments. Nevertheless, $P$. koreni can also be found in coarser sediment with a median grain size up to $500 \mu \mathrm{m}$ (Vovelle, 1973). The slightly curved tube (diameter $=0.8 \mathrm{~cm}$, total length up to $8 \mathrm{~cm}$ ) is constructed with medium-sized sand grains and is buried in the sediment with the worm upside down. This species has an aggregative distribution with patches reaching densities of several hundreds of individuals per square meter. But the gregariousness of this species is relative. This sub-surface deposit-feeder is responsible for important bioturbation of the surrounding sediments (Nichols, 1974; Busch and Loveland, 1975; Dobbs and Scholly, 1986).

Lanice conchilega (Pallas, 1766) [Terrebeliidae] is one of the most common tube-building polychaetes in the Northern European sandflats (Strasser and Pieloth, 2001; Reise, 2002; Fig. 1(b)). This amphiboreal species ranges from intertidal to subtidal (up to $100 \mathrm{~m}$ depth) environments and inhabits fine to coarse sediments (Rabaut et al., 2007). Populations are mainly concentrated below the low water neap tide level. This tubebuilder has an aggregative distribution with patches reaching densities of several thousands of individuals per square meter (up to 5000 ind. $\mathrm{m}^{-2}$ in the bay of Mont-Saint-Michel; Godet et al., 2008, 2009; Fig. 1(c)). The L. conchilega tube (diameter $=0.5 \mathrm{~cm}$, total length up to $65 \mathrm{~cm}$ ) is prolonged by sand-fringes which protrude from the sediment and impact the local hydrosedimentary environment (Toupoint et al., 2008). Above a threshold density, current velocities decrease within clusters, deposition of fine sediment particles is facilitated and mounds (up to $1 \mathrm{~m}$ high) are created (Féral, 1989; Zühlke, 2001).

Sabellaria alveolata Linnaeus, 1767 [Sabellariidae] is well known for the building of extended reefs along the shores of Northwestern Europe, from Wales to Morocco. Reefs are found on the lower shore and below on hard substrates. In the bay of Mont-Saint-Michel, colonies form reefs over $1.8 \mathrm{~m}$ in thickness (Fig. 1(d, e)). This species can form important colonies by the juxtaposition of their sand-tubes which form dense and solid mounds of various shapes and sizes (Dubois et al., 2002, 2003). The average grain-size increases toward the distal end of the tube. By showing preference for shell fragments, S. alveolata reinforce the rigidity of their tubes at a reduced cost since the bioclastic grains have a large surface area per unit of mass. This species uses a large spectrum of sediment class sizes and actively controls the texture of the surrounding sediments.

Phragmatopoma caudata (Krøyer) Mörch, 1863 [Sabellariidae] constructs massive reef-like mounds in one major form such as ball-shaped structures over $0.5 \mathrm{~m}$ thick (Kirtley and Tanner, 1968; Fig. 1(f, g)). This species is common on rocky platforms and uses a large spectrum of sediment class sizes (Main and Nelson, 1988). P. caudata reefs are found over a wide area of the western Atlantic coastline from Florida (USA) to the Santa Catarina State in Brazil. Reefs are located in highenergy environments. Factors which control the abundance and distribution of the reefs of Sabellariidae include requirements such as the availability of a stable substrate (rocky platforms, beach-rocks), appropriate levels of wave- and current-induced turbulence and the availability of sediment with well-defined class-sizes and shape.

The nature of the sand masonry of several marine polychaetes is now well known. Phragmatopoma spp. cement consists of proteinic substances (glycine, serine, alanine) that bear similarities to sericin, the silk protein (Waite, 1987; Jensen and Morse, 1988; Waite et al., 1992; Zhao et al., 2005), and significant levels of phosphorus, calcium and magnesium (Gruet et al., 1987). This proteinaceous cement has a microporous foam structure and seems to be made up of hollow spheroids in a matrix (Stewart et al., 2004). It is 
Pectinaria koreni Lanice conchilega

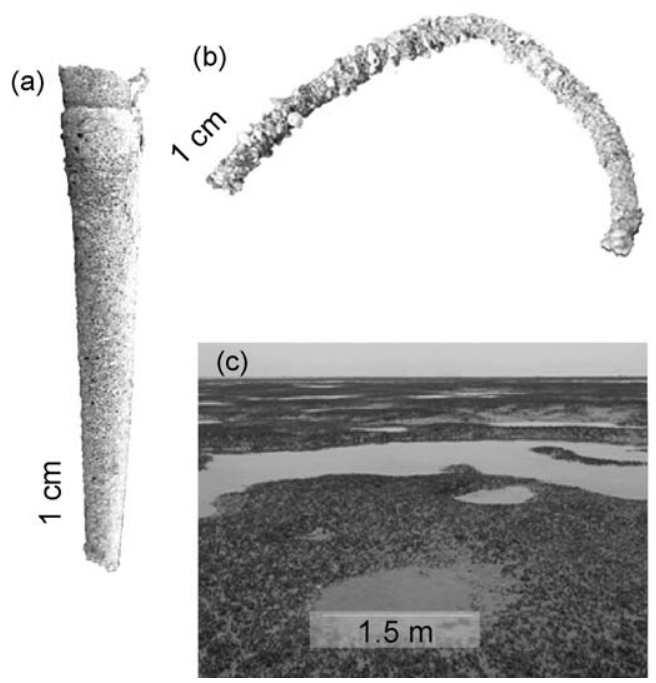

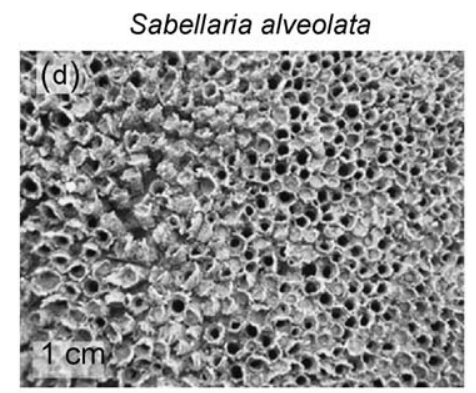

(e)

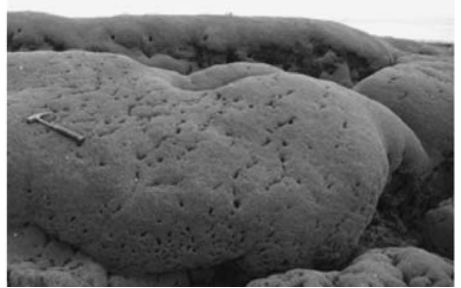

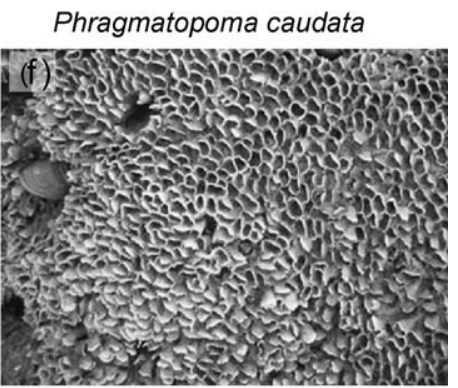

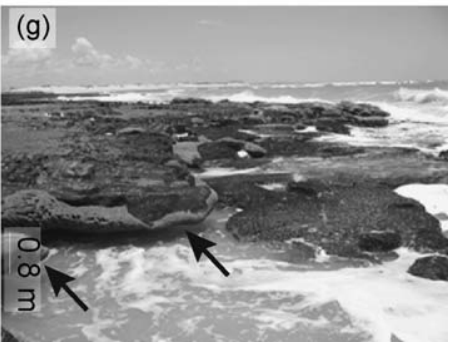

Fig. 1. Photographs of tubes and reefs. (a) Close-up of one tube of Pectinaria koreni sampled in the Bay of Le Croisic, France; (b) Close-up of one tube of Lanice conchilega sampled in the Bay of Mont-Saint-Michel, France; (c) General view of a typical bed of L. conchilega with thousands individuals per square meter taken in the central part of the Bay of Mont-Saint-Michel; Close-up of the tubes of Sabellaria alveolata (d) and reef (e) taken in Champeaux, eastern part of the Bay of MontSaint-Michel; Close-up of the tubes of Phragmatopoma caudata (f) taken in Mel Island, State of Paraná, Brazil, and reef (g, arrows) taken in Tibau do Sul, State of Rio Grande do Norte, Brazil.

produced by two types of large unicellular glands, situated in the thorax of the worm, containing homogeneous or heterogeneous secretory granules (Vovelle, 1965). Homogeneous material is used to form the matrix whereas spheroids derive directly from inclusion of the heterogeneous granules (Flammang and Lambert, 2008). Differential $\mathrm{pH}$ between secretory glands and seawater might explain the drying out reaction mechanism (coacervation model) involving, first, a rapid (30 s) change in the nature of the bonding of divalent cations with protein $\mathrm{Pc} 3$, and then, a second reaction characterized by a slower hardening of the cement (Zhao et al., 2005; Stevens et al., 2007). Stability of the cement is achieved, for $S$. alveolata, by internal quinone tanning (Gruet et al., 1987), but calcium or magnesium depletion can affect the structural and mechanical properties of the cement by lowering pull-out forces and tube compressive strength (Sun et al., 2007). Most studies undertaken on these cements have been monospecific and examined their nature and properties; comparative works between these tube-building species have never been undertaken.

The aim of this study is to compare the inter- and intraspecific variability in the main biomineral components of cement at local, regional or continental scales by testing the following hypotheses:

- Are the components of the cement the same between isolated tube-building (P. koreni, L. conchilega) and reef-building (S. alveolata, $P$. caudata) species and between scattered $(P$. koreni) and gregarious species (L. conchilega, S. alveolata and $P$. caudata)?

- Are the concentrations of the pre-identified elements the same at different locations for the same species and for different species at the same location?

\section{Materials and methods}

\subsection{Study sites and sampling method}

The study was carried out both in the Bay of Mont-SaintMichel (Southwestern part of the Channel, France), whose main characteristic is the presence of well developed reefs of $S$. alveolata and beds of $L$. conchilega and along the whole coast of Brazil from Ceará State $\left(3^{\circ} S\right)$ in the North to Santa Catarina State $\left(28^{\circ} S\right)$ in the South for $P$. caudata reefs.

Several tubes of $L$. conchilega were collected individually in the main patch located in the central part of the bay of Mont-Saint-Michel (Table 1). Tubes of $P$. koreni were collected individually in the eastern part of the bay of Le Croisic, located on the southern coast of Brittany, because this species is very rare in the bay of Mont-Saint-Michel and resides only in the subtidal area. Tubes of $S$. alveolata were collected in Champeaux reef located in the eastern part of the bay of Mont-Saint-Michel, in Ste-Anne reef located in the central part of the bay of Mont-Saint-Michel and in Planguenoual reef located in the eastern part of the bay of St-Brieuc (Fig. 2).

Samples of $P$. caudata were collected from seven sites in Brazil (Florianópolis, Santa Catarina [SC]; Ilha do Mel, Paraná [PR]; Ubatuba, São Paulo [SP]; Trindade, Rio de Janeiro [RJ]; João Pessoa, Paraíba [PB]; Tibau do Sul, Rio Grande do Norte [RN] and Fortaleza, Ceará [CE]; Fig. 3). When they were present, worms were removed from the tubes. Individual tubes or reef fragments (for Sabellariids species) were washed carefully with distilled water and then stored into individual hermetic plastic bags. Samples were air-dried before analysis (Gruet et al., 1987; Stewart et al., 2004). 
Table 1

Location of sampled reefs.

\begin{tabular}{|c|c|c|c|}
\hline Species & Location & Geographical coordinates & Sampling date \\
\hline L. conchilega & France, Mont-St-Michel, central part & $48^{\circ} 39^{\prime} \mathrm{N}-1^{\circ} 38^{\prime} \mathrm{W}$ & August 2006 \\
\hline S. alveolata & $\begin{array}{l}\text { France, Mont-St-Michel, Champeaux } \\
\text { France, Mont-St-Michel, Ste-Anne reef } \\
\text { France, St-Brieuc, Planguenoual reef }\end{array}$ & $\begin{array}{l}48^{\circ} 43^{\prime} \mathrm{N}-1^{\circ} 33^{\prime} \mathrm{W} \\
48^{\circ} 39^{\prime} \mathrm{N}-1^{\circ} 39^{\prime} \mathrm{W} \\
48^{\circ} 33^{\prime} \mathrm{N}-2^{\circ} 36^{\prime} \mathrm{W}\end{array}$ & $\begin{array}{l}\text { September } 2006 \\
\text { February } 2007 \\
\text { February } 2007\end{array}$ \\
\hline P. koreni & France, Le Croisic & $47^{\circ} 17^{\prime} \mathrm{N}-2^{\circ} 29^{\prime} \mathrm{W}$ & September 2006 \\
\hline P. caudata & $\begin{array}{l}\text { Brazil, Florianópolis, Santa Catarina } \\
\text { Ilha do Mel, Paraná } \\
\text { Ubatuba, São Paulo } \\
\text { Trindade, Rio de Janeiro } \\
\text { João Pessoa, Paraíba } \\
\text { Tibau do Sul, Rio Grande do Norte } \\
\text { Fortaleza, Ceará }\end{array}$ & $\begin{array}{l}27^{\circ} 48^{\prime} \mathrm{S}-48^{\circ} 32^{\prime} \mathrm{W} \\
25^{\circ} 34^{\prime} \mathrm{S}-48^{\circ} 18^{\prime} \mathrm{W} \\
23^{\circ} 22^{\prime} \mathrm{S}-44^{\circ} 50^{\prime} \mathrm{W} \\
23^{\circ} 21^{\prime} \mathrm{S}-44^{\circ} 43^{\prime} \mathrm{W} \\
7^{\circ} 08^{\prime} \mathrm{S}-34^{\circ} 47^{\prime} \mathrm{W} \\
6^{\circ} 10^{\prime} \mathrm{S}-35^{\circ} 05^{\prime} \mathrm{W} \\
3^{\circ} 48^{\prime} \mathrm{S}-38^{\circ} 24^{\prime} \mathrm{W}\end{array}$ & $\begin{array}{l}\text { October } 2005 \\
\text { November } 2006 \\
\text { November } 2006 \\
\text { November } 2006 \\
\text { February } 2006 \\
\text { February } 2006 \\
\text { March } 2006\end{array}$ \\
\hline
\end{tabular}

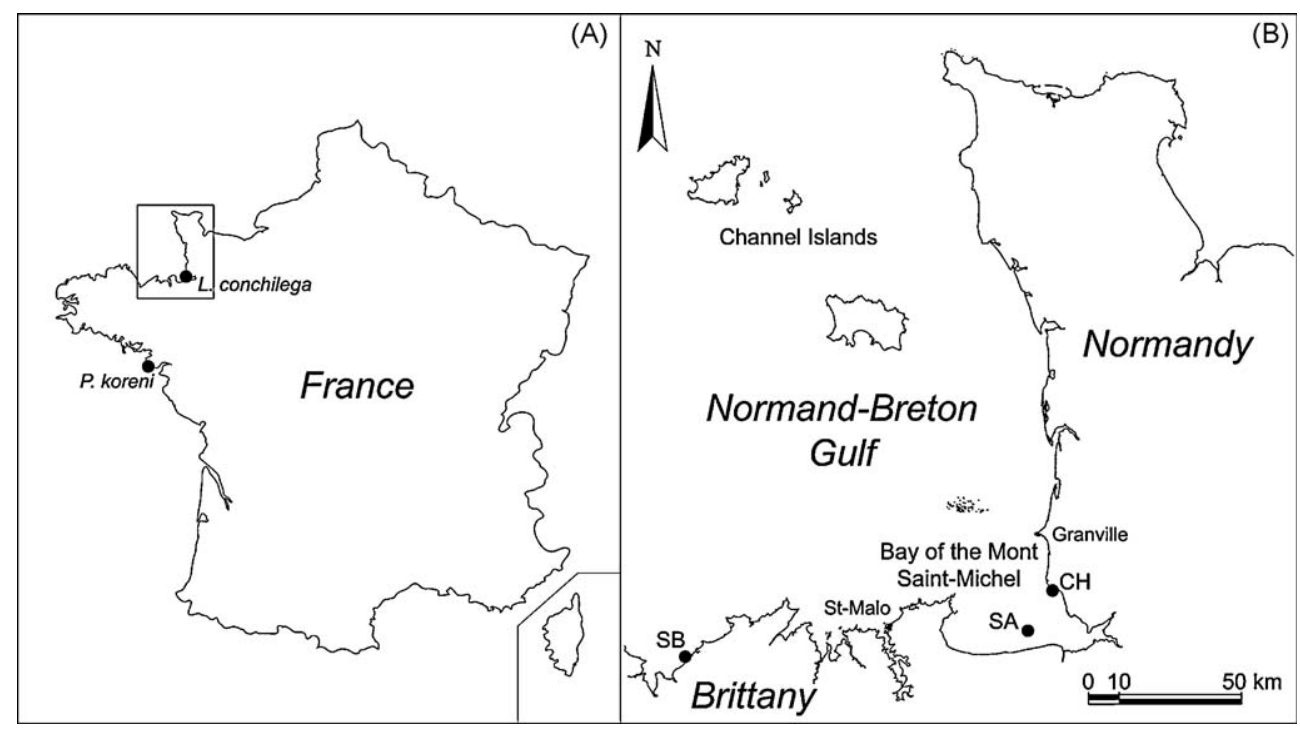

Fig. 2. Localisation map of the samples of L. conchilega (Bay of Mont-Saint-Michel) and P. koreni (Le Croisic) (A) and of S. alveolata (B). CH: Reef of Champeaux (Manche); SA: Reef of Sainte-Anne (Ille-et-Vilaine); SB: Reef of Planguenoual (Côtes-d'Armor).

\subsection{Procedures for Electron Probe Micro-Analysis (EPMA)}

Analyses were made on polychaetes tube slices impregnated with Epofix, a cold-setting resin based on two fluid epoxy components. It is specially developed for impregnation of porous specimens like Sabellaria or Phragmatopoma tubes. Owning to its low viscosity, Epofix penetrates into all porosities and cracks of the tubes. In order to facilitate penetration and degassing, impregnated samples were maintained in a vacuum chamber during the solidification phase. Epofix blocks were sectioned into two pieces using a STRUERS Minitom automatic precision cut-off machine. Lower pieces were conserved and manually polished using $1200 \mu \mathrm{m}$ to $200 \mu \mathrm{m}$ silicon carbide paper. After manual polishing, samples have been cleaned using a FISHER Bioblock Scientific ultrasonic cleaning machine. Mechanical polishing has been performed with a PRESI Mecapol P-200 polishing machine using three PRESI Mecaprex polishing solutions in succession $(6 \mu \mathrm{m}, 3 \mu \mathrm{m}$ and $0.25 \mu \mathrm{m})$. Samples were then coated with carbon and cement composition was analysed using a CAMECA SX100 Electron Probe Micro-Analyser. Calcium (Ca), Phosphorus (P), and Magnesium (Mg) contents were measured (calibration: calcite, apatite, and dolomite, respectively) according to Gruet et al. (1987), Stewart et al. (2004) and Sun et al. (2007). Focused electron beam width was $8 \mathrm{~nm}$. After the mounting procedure, 19 samples consisting of several leveled tubes (at least 10 tubes per sample) were analyzed. Each species was represented by 3 samples, except $P$. caudata for which 10 samples were processed, allowing intraspecific analysis. Eight to 15 cement sites have been selected per sample and each site was analyzed 4 times (60 seconds per counting).

\subsection{Procedures for Scanning Electron Microscopy Analysis}

Both rough and impregnated samples were observed under a JEOL-JSM 5810LV scanning electron microscope. Rough samples were air-dried for several weeks, mounted on an aluminium plate and coated with carbon. Observations were 


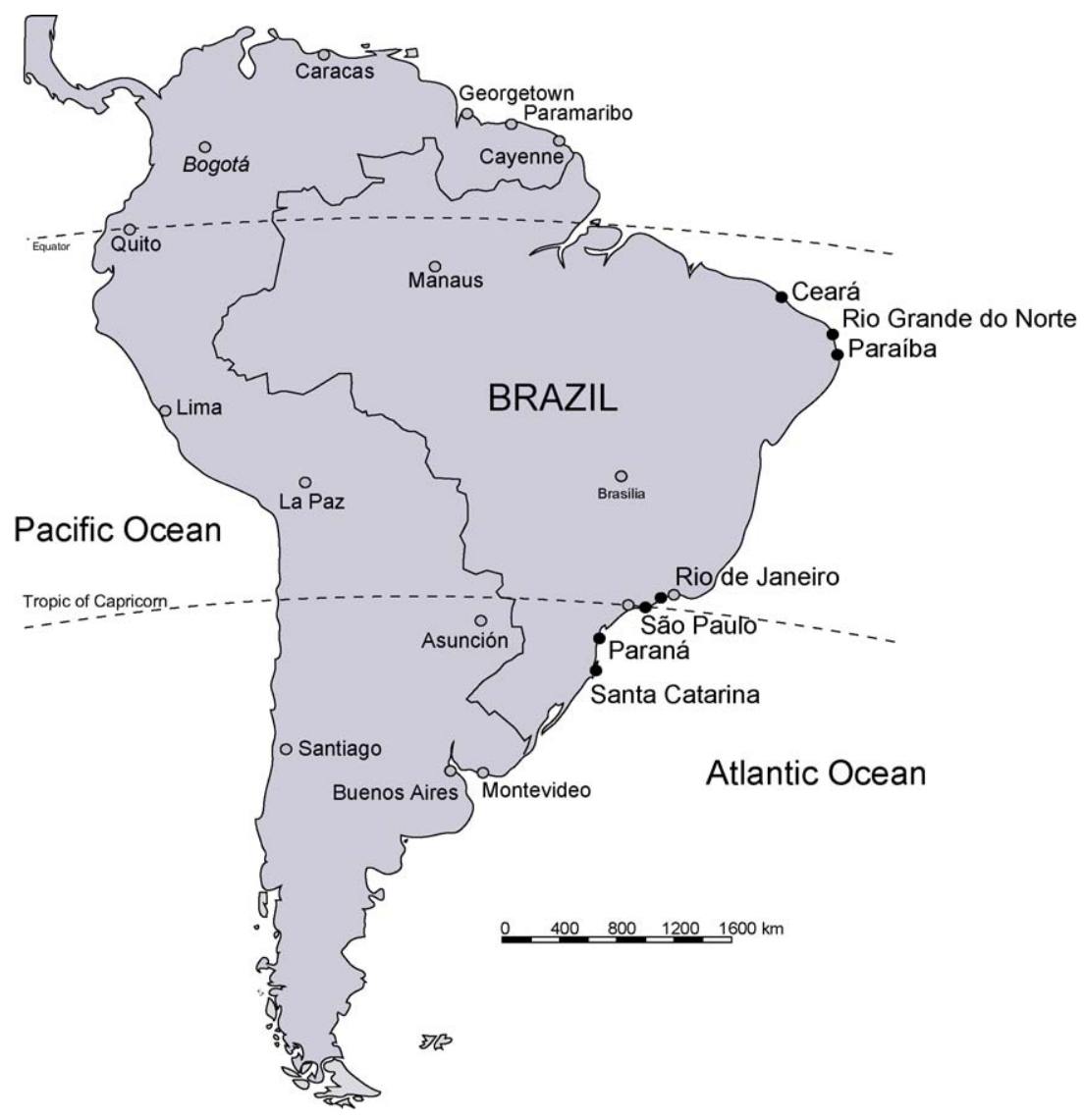

Fig. 3. Localisation map of the samples of $P$. caudata.

restricted to secondary electron imagery which allows relief characterization of rough samples. Indeed, SEI allows the observation of the external structure of tubes in three dimensions. Sliced samples previously analyzed with EPMA were observed under back-scattered electron mode. Image resolution is higher under SEM than EPMA, thus allowing characterization of the internal structure of the tube and the observation of grain/cement relationships (Truchet and Vovelle, 1977).

\subsection{Data analysis}

Differences between element contents of the cement were tested using one-way ANOVA. The assumptions of normality and homoscedasticity were verified by direct observation of residuals, Kolmogorov-Smirnov tests, Lilliefors tests and Levene tests or Brown-Forsythe tests, respectively, with Statistica v.6.1 software. In multivariate analysis based on quantitative data, transformations are used to weight the relative contribution of each element contents (Zar, 1999). As a result, data were square-root transformed before using one-way ANOVA (Field et al., 1982). Finally, post-hoc comparisons were performed through HSD Tukey tests (Scherrer, 1984). To compare cement component variability, we followed the methods of Clarke and Warwick (1994) and used the Plymouth Routines in Multivariate Ecological Research (PRIMER) version v6.1.6 software (Clarke and Gorley, 2006). Non-metric multidimensional scaling ordinations (nMDS) and analysis of similarity (one-way ANOSIM) were performed after computation of a Bray-Curtis similarity matrix (Legendre and Legendre, 1998). The nMDS technique takes a distance matrix and plots all the samples in the configuration that best satisfies all the rank constraints of the matrix. Therefore, samples with the greatest similarity will be plotted closest together. Stress values related to nMDS plots indicate the goodness of representation of dissimilarities between samples. A stress value $<0.1$ corresponds to an excellent representation of the data with little chance of a misleading diagram. Stress value between 0.1 and 0.3 still provide a potentially useful picture, although the detail of the plot cannot be considered truly accurate. Moreover, the similarities within and between the cement of species were identified by the SIMPER subroutine of the PRIMER software.

\section{Results}

\subsection{Interspecific variability}

Differences for $\mathrm{Ca}, \mathrm{P}$ and $\mathrm{Mg}$ concentrations between samples of each species were tested. Fig. 4 shows the mean of each element and 95\% confidence intervals for all studied species. No significant differences were found for samples of $L$. conchilega and $S$. alveolata. Significant differences appear only for $\mathrm{Mg}$ content of $P$. koreni $\left(F_{(2,18)}=6.384 ; p<0.01\right)$ and $P$. caudata $\left(F_{(2,22)}=5.907 ; p<0.01\right)$ cements. 

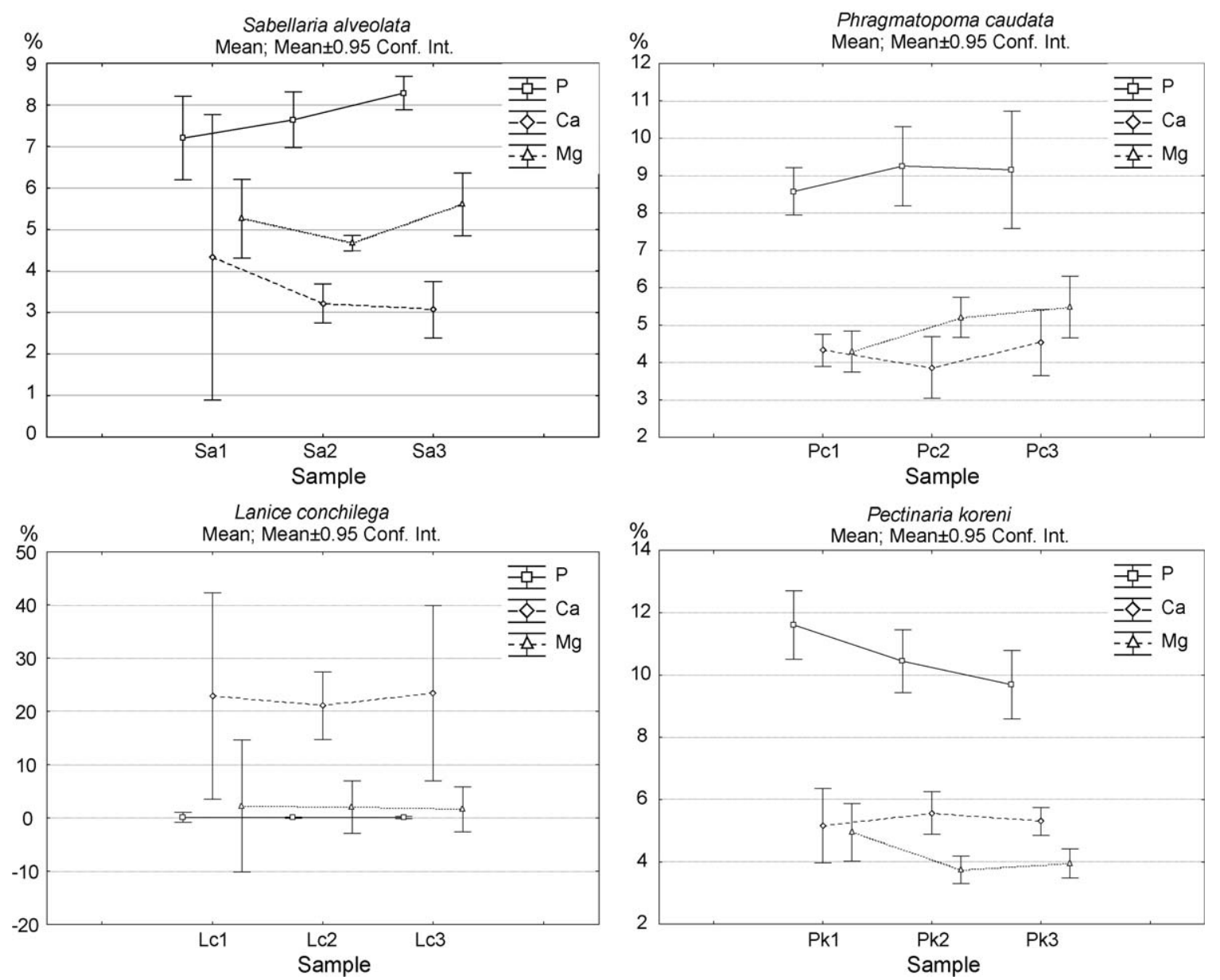

Fig. 4. Means and 95\% confidence intervals of $\mathrm{P}, \mathrm{Ca}$ and $\mathrm{Mg}$ contents for the cement of S. alveolata, P. caudata, L. conchilega and P. koreni.

Correlations between elements were performed and showed a significant relation between $\mathrm{P}$ and $\mathrm{Mg}$ for $P$. koreni $(r=0.764$; $p<0.001)$, P. caudata $(r=0.699 ; p<0.001)$ and $S$. alveolata $(r=0.716 ; p<0.005)$. A negative correlation was found between $\mathrm{Ca}$ and $\mathrm{Mg}(r=-0.677 ; p<0.01)$ and between $\mathrm{Ca}$ and P for S. alveolata $(r=-0.731 ; p<0.005)$ (Clark, 1965). On the other hand, a positive correlation was found between $\mathrm{Ca}$ and $\mathrm{P}$ for $P$. caudata $(r=0.490 ; p<0.05)$. The SIMPER analysis shows that the average similarity of the cement for each species is high $(88.74 \%$ for P. caudata; $91.78 \%$ for $S$. alveolata; $91.57 \%$ for P. koreni and $94.00 \%$ for L. conchilega).

Comparisons between species show that the concentration of elements are of high significant difference $\left(\mathrm{Ca}: F_{(3,61)}=373.550\right.$ $p<0.001 ; \mathrm{Mg}: F_{(3,61)}=28.039 p<0.001 ; \mathrm{P}: F_{(3,61)}=394.780$ $p<0.001)$. Post-hoc tests do not reveal any difference between $S$. alveolata and $P$. caudata for $\mathrm{Ca}$ and $\mathrm{Mg}$ content, but a significant difference for $\mathrm{P}$ appears between both species (HSD Tukey test $p<0.01$ ). The concentration of elements of the cement between L. conchilega and $P$. koreni is of high significant difference $(\mathrm{Ca}$ and $\mathrm{Mg}$ : HSD Tukey test $p<0.001$; P: HSD Tukey test $p<0.001)$ as well as for the two species of Sabellariidae (Ca and Mg: HSD Tukey test $p<0.05$; P: HSD Tukey test $p<0.01$ ). The SIMPER analysis confirms that the average dissimilarity is low between the two species of
Sabellariidae $(11.00 \%)$ and can be attributed mainly to the $\mathrm{P}$ content (total contribution $=40.58 \%$ ). The average dissimilarity between the two tube-building species, L. conchilega and $P$. koreni, is very high $(66.59 \%)$ and can be attributed mainly to the $\mathrm{Ca}$ content (total contribution $=57.88 \%$ ). The highest average dissimilarity was found between the two reef-building species $(P$. caudata, S. alveolata) and L. conchilega $(71.93 \%$ and $74.76 \%$, respectively) and can be attributed to the Ca content (total contribution $=63.33 \%$ and $65.13 \%$, respectively). The average dissimilarity between the two species of Sabellariidae and $P$. koreni was low (P. caudata $14.26 \%$, S. alveolata $18.13 \%$ ) and can be attributed to the P content ( $45.85 \%$ and $44.64 \%$, respectively).

The dendrogram and the nMDS plot of the hierarchical cluster analysis reveal two groups isolated at a similarity level of $c a .74 \%$ (Fig. 5). At a $74 \%$ similarity threshold, $L$. conchilega and the three other species are separated. ANOSIM pairwise tests show that both species of Sabellariidae are not significantly different (ANOSIM $p=12.4 \% ; R=0.074$ ).

Others pairwise tests, illustrated by nMDS plot (Fig. 6), show significant differences between $P$. caudata and $P$. koreni (ANOSIM $p=0.01 \% ; R=0.320$ ) and between $S$. alveolata and P. koreni (ANOSIM $p=0.01 \% ; R=0.894$, fourth-root transformed data). The differences highlighted can be explained both by interspecific differences and differences in 


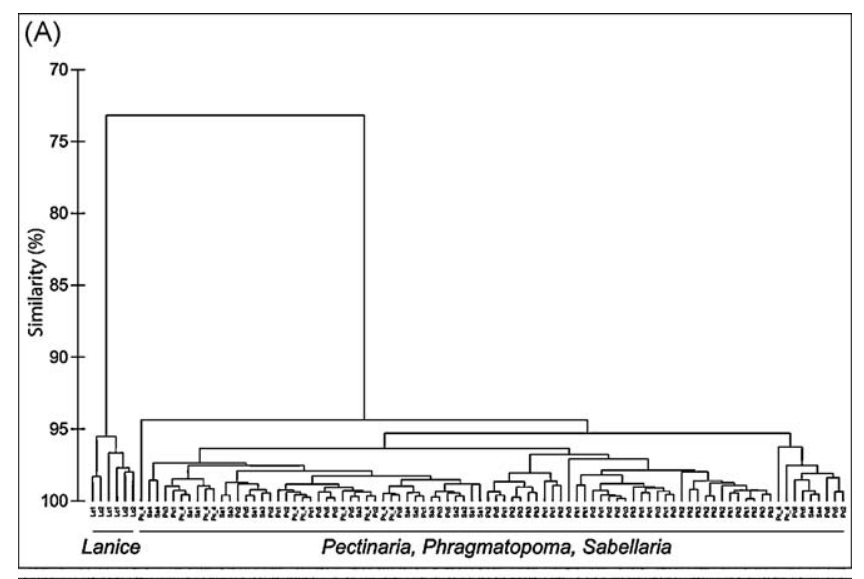

(B)

2D Stress: 0.01

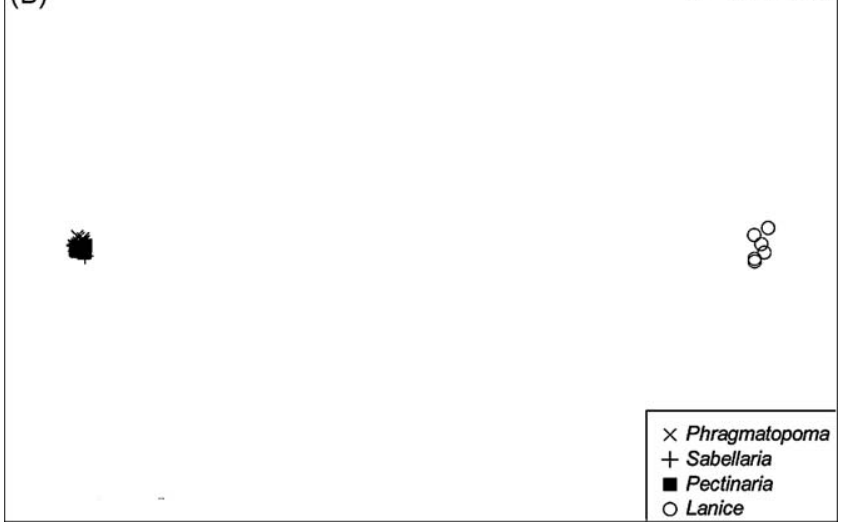

Fig. 5. Dendrogram of the hierarchical cluster analysis (fourth root-transformed) obtained from the $\mathrm{P}, \mathrm{Ca}$ and $\mathrm{Mg}$ contents of the cement for the four species (A) and corresponding non-metric multidimensional scaling (nMDS) ordination plot based on the Bray-Curtis similarity (B).

environmental conditions. Complementary analysis will be necessary to determine it.

\subsection{Intraspecific variability}

Intraspecific variability has been tested for both species of Sabellariidae: S. alveolata in three stations located in the Bay of Saint-Brieuc and in the Bay of Mont-Saint-Michel, and $P$. caudata in seven stations along the brazilian coast from Ceará State in the North to Santa Catarina State in the South. Comparisons between stations for $S$. alveolata show that the concentration of elements are significantly different for $\mathrm{P}$ $\left(F_{(2,16)}=3.864 ; \quad p<0.05\right) \quad$ and $\quad \mathrm{Mg} \quad\left(F_{(2,16)}=16.501\right.$; $p<0.001)$. Post-hoc tests do not reveal any difference between stations for $\mathrm{P}(p>0.05)$. A significant difference for $\mathrm{Mg}$ has been found between the station of the Bay of Saint-Brieuc (Planguenoual $[\mathrm{SB}]$ ) and the two others from the Bay of MontSaint-Michel (Sainte-Anne reef [SA] $p<0.05$; Champeaux reef $[\mathrm{CH}] p<0.001)$. However, the SIMPER analysis shows that the average dissimilarity is very low between the stations (2.36\% for $\mathrm{CH}$ and $\mathrm{SA} ; 2.96 \%$ for $\mathrm{CH}$ and $\mathrm{SB}$ and $2.45 \%$ for $\mathrm{SA}$ and $\mathrm{SB}$ ) and can be attributed mainly to the $\mathrm{Mg}$ content (total contribution $=41.75 \%$ for $\mathrm{CH}$ and $\mathrm{SA} ; 64.21 \%$ for $\mathrm{CH}$ and $\mathrm{SB}$; $42.27 \%$ for SA and SB). ANOSIM pairwise tests, illustrated by

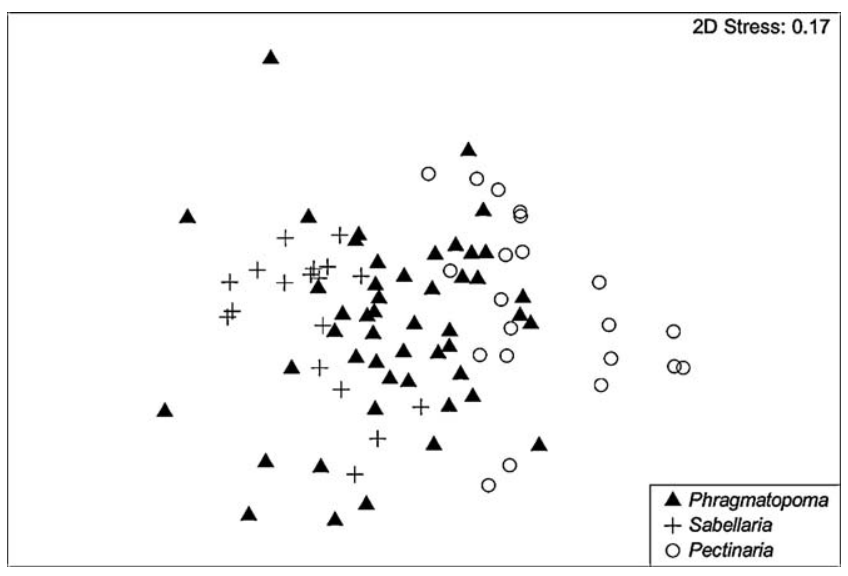

Fig. 6. Non-metric multidimensional scaling (nMDS) ordination plot based on the Bray-Curtis similarity (fourth root-transformed data) showing the interspecific differences of the cements between $P$. caudata, $S$. alveolata and $P$. koreni.

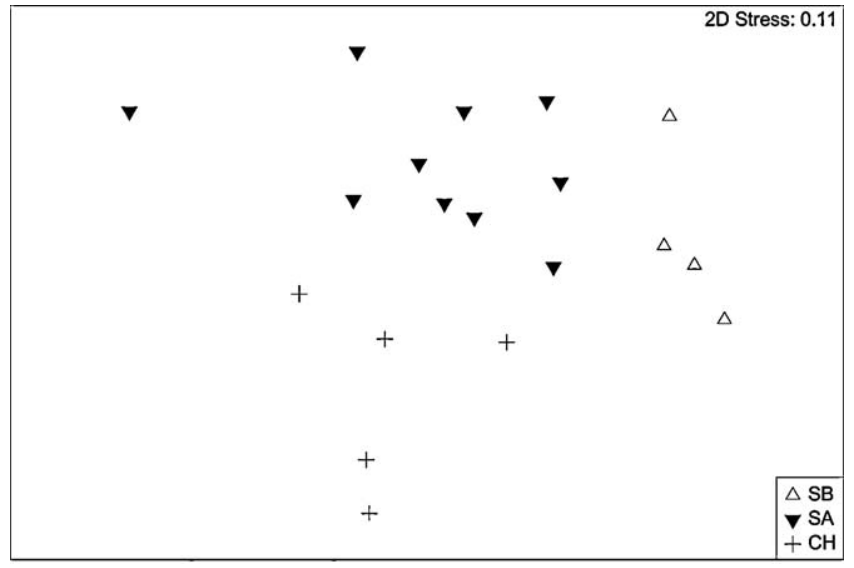

Fig. 7. Non-metric multidimensional scaling (nMDS) ordination plot based on the Bray-Curtis similarity (fourth root-transformed data) showing the intraspecific differences of the cement of $S$. alveolata between stations of the Bay of Saint-Brieuc and the Bay of Mont-Saint-Michel. CH: Reef of Champeaux (Manche); SA: Reef of Sainte-Anne (Ille-et-Vilaine); SB: Reef of Planguenoual (Côtes-d'Armor).

nMDS plot (Fig. 7), show significant differences between $\mathrm{CH}$ and SA (ANOSIM $p=0.2 \% ; R=0.557$ ) and between SA and SB (ANOSIM $p=0.2 \% ; R=0.573$ ).

The composition of the cement between stations for $P$. caudata along the whole brazilian coast are of a high significant difference for each studied element: $\mathrm{P} \quad\left(F_{(6,42)}=22.532\right.$; $p<0.001) ; \quad \operatorname{Mg} \quad\left(F_{(6,42)}=19.320 ; \quad p<0.001\right) ; \quad$ and $\mathrm{Ca}$ $\left(F_{(6,42)}=9.416 ; p<0.001\right)$. Post-hoc tests show that two main groups are significantly different and can be separated for $\mathrm{P}$ $(p<0.05)$ and $\mathrm{Mg}(p<0.05)$. The first one clusters stations from the Southern coast of Brazil (SC, PR, SP and RJ) and the second one stations from the Northern coast of Brazil (RN and $\mathrm{CE}$ ). The State of Paraíba (PB) seems to be in an intermediate position between the two groups. For Ca, post-hoc tests were computed and showed significant differences between three groups $(p<0.05)$ : SC and PR (Southern coast of Brazil), SP, $\mathrm{RJ}$ and PB (Central part of brazilian coast), and RN and CE 


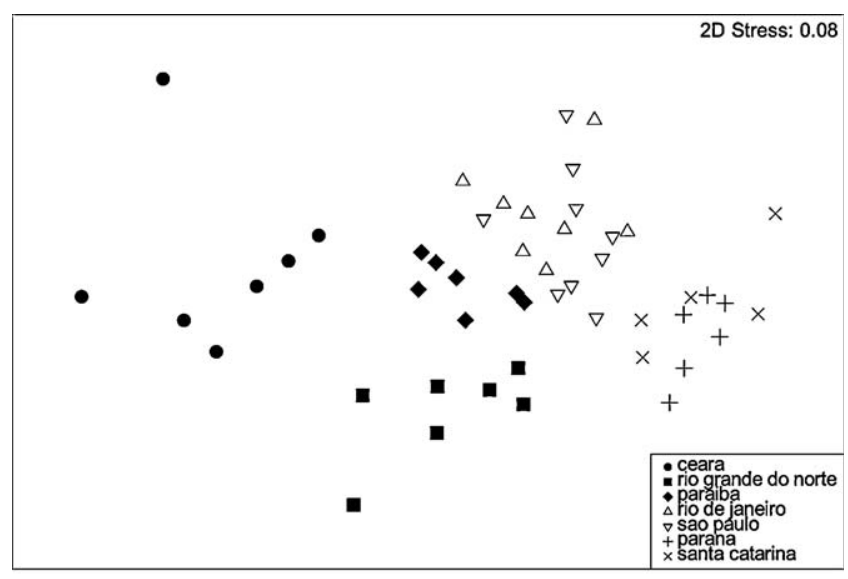

Fig. 8. Non-metric multidimensional scaling (nMDS) ordination plot based on the Bray-Curtis similarity (fourth root-transformed data) showing the intraspecific differences of the cement of $P$. caudata between stations along the whole coast of Brazil, from the State of Ceará in the north to the State of Santa Catarina in the south.

(Northern coast of Brazil). The SIMPER analysis shows that the average dissimilarity between stations from the extreme South (SC, PR) and North (RN, CE) (5.00\%) can be attributed to the P content (total contribution $=36.92 \%$ ) and $\mathrm{Mg}$ content (total contribution $=36.92 \%)$. The average dissimilarity between stations from the Central and Southern regions is lower (2.66\%; $\mathrm{Ca}$ total contribution $=51.20 \%$ ) than between stations from the Central and Northern regions $(3.50 \%$; $\mathrm{Mg}$ total contribution $=44.28 \%)$. The best average dissimilarity was obtained with SC vs. CE $(6.58 \%$; Mg total contribution $=36.94 \%)$ and PR vs. CE $(6.60 \%$; P total contribution $=34.05 \%)$. ANOSIM pairwise tests, illustrated by nMDS plot (Fig. 8), show significant differences between each region: North vs South (ANOSIM $p=0.01 \% ; R=0.745$ ); Central $v s$ South (ANOSIM $p=0.01 \% ; R=0.749)$; Central $v s$. North (ANOSIM $p=0.01 \%$; $R=0.685$ ). The best $\mathrm{R}$ was obtained with $\mathrm{SC} / \mathrm{SP} / \mathrm{RJ} v s . \mathrm{CE}$ (ANOSIM $p=0.1 \% ; \quad R=0.994, \quad p=0.04 \% ; \quad R=0.947$, $p=0.02 \% ; R=0.907$, respectively) and SC $v s$. PB (ANOSIM $p=0.1 \% ; R=0.954)$.

\section{Discussion and conclusion}

The study of polychaete cements has encountered a renewed interest in recent years due to their particular mechanical properties (Sun et al., 2007; Shao et al., 2009). Proteinic characteristics of the cement have focused nearly all interests (Jensen and Morse, 1988; Waite et al., 1992; Stewart et al., 2004; Zhao et al., 2005; Stevens et al., 2007), whereas its mineral phase has been largely neglected (Gruet et al., 1987; Sun et al., 2007). Cement generated by tube-building species is essential to understand biogeomorphological processes in Sabellariidae reefs or Terrebeliidae beds (Murray et al., 2002). Resistance and flexibility are required to allow these bioconstructions to manage varying hydrodynamical stress. Sun et al. (2007) have demonstrated that $\mathrm{Ca}$ and $\mathrm{Mg}$ play a premium role in the resistance of the cement to physical stress. This study shows that the mineral phase of the cement of the four studied species is mainly composed of $\mathrm{P}, \mathrm{Ca}$ and $\mathrm{Mg}$; all elements being strongly correlated. $\mathrm{Mn}$ and $\mathrm{Fe}$ are additional minor elements encountered in the cement whose presence is common in $\mathrm{Ca}-\mathrm{Mg}$ concretions of marine invertebrates (Simkiss, 1983). Our results confirm those of Gruet et al. (1987) for $S$. alveolata, Truchet and Vovelle (1977) and Vovelle and Grasset (1990) for P. koreni, and Lafon (1959) for L. conchilega. Phragmatopoma caudata cement has never been studied before, whereas Phragmatopoma californica has been studied by Stewart et al. (2004), Sun et al. (2007), and Zhao et al. (2005). Our results show that the cement of both species is very close in term of mineral composition and physical structure.

Cements have a foam-like structure with micrometric voids (Fig. 9). SEM images also reveal that $P$. koreni cement (this study and Vovelle and Grasset, 1990) is similar to that produced by reef-building species such as those of the Sabellariidae family: S. alveolata (this study and Gruet et al., 1987), $P$. caudata (this study) and P. californica (see pictures in Stewart et al., 2004; Stevens et al., 2007). The same mineral phase (P, $\mathrm{Ca}, \mathrm{Mg}$ ) is encountered in these tube-building polychaetes, but proportions of the three studied elements vary greatly between species. Different analytical procedures of the samples were used in the studies, so quantitative data could not be compared here. Statistical tests show that both reef-building sabellariid species ( $S$. alveolata and $P$. caudata) cannot be differentiated from other tube-building engineer species, i.e. L. conchilega and $P$. koreni, the latter having a less-pronounced influence on surrounding sediment features. Hence, the chemical signature of the organic cement does not typify the studied tube-building species.

Considering inter-specific variations, $L$. conchilega cement differs significantly from the three other cements for the three elements analysed. The cement of the three other species is very similar, although $\mathrm{P}$ content variation is statistically significant to discriminate the three species. Considering intra-specific variations, we have tested the mineral phase of the cement as a discriminating element between isolated populations. Statistical analyses show that significant differences exist between studied populations, even though these differences are weak.

On a regional scale, it has been possible to distinguish $S$. alveolata populations from Saint-Brieuc Bay from those of the Mont-Saint-Michel Bay, isolation being based mainly on $\mathrm{Mg}$ content, secondly on $\mathrm{P}$ content. Considering the present knowledge, it is not possible to know if the environment (e.g., physical and chemical composition of seawater) is responsible for the differences recorded, although it has been demonstrated recently that, on the genetic scale, both populations belong to the same meta-population (Farcy, 2003; Rigal, 2005).

On a continental scale, it has been possible to separate $P$. caudata populations distributed along the Brazilian coast. P and $\mathrm{Mg}$ contents are significant variables, allowing a discrimination between southern populations (Santa Catarina, Paraná, São Paulo and Rio de Janeiro States) and northern populations (Rio Grande do Norte and Ceará States). The population of Paraíba State has an intermediate position between both groups. Ca, although less distinctive, reinforces the three-fold separation. The first group gathers southern populations (Santa Catarina 


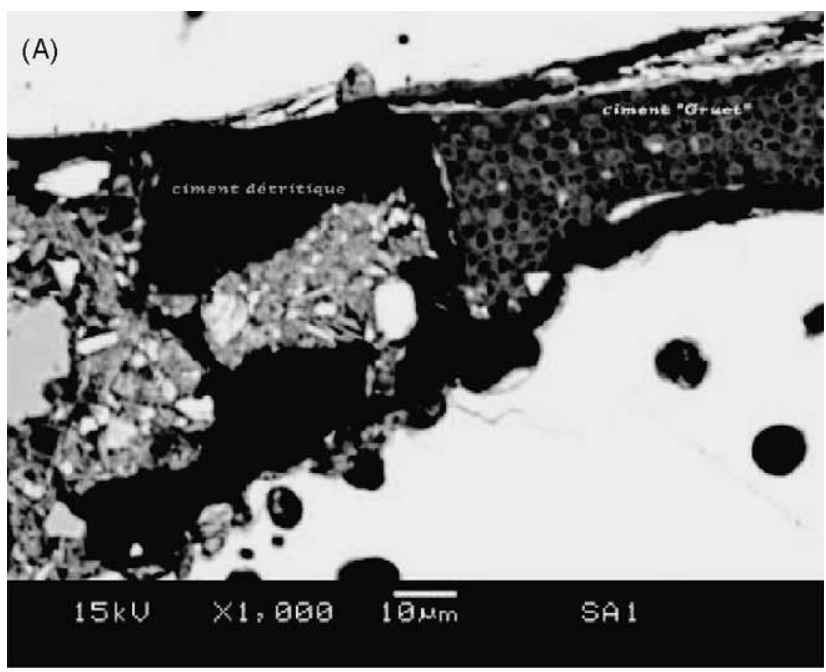

(B)
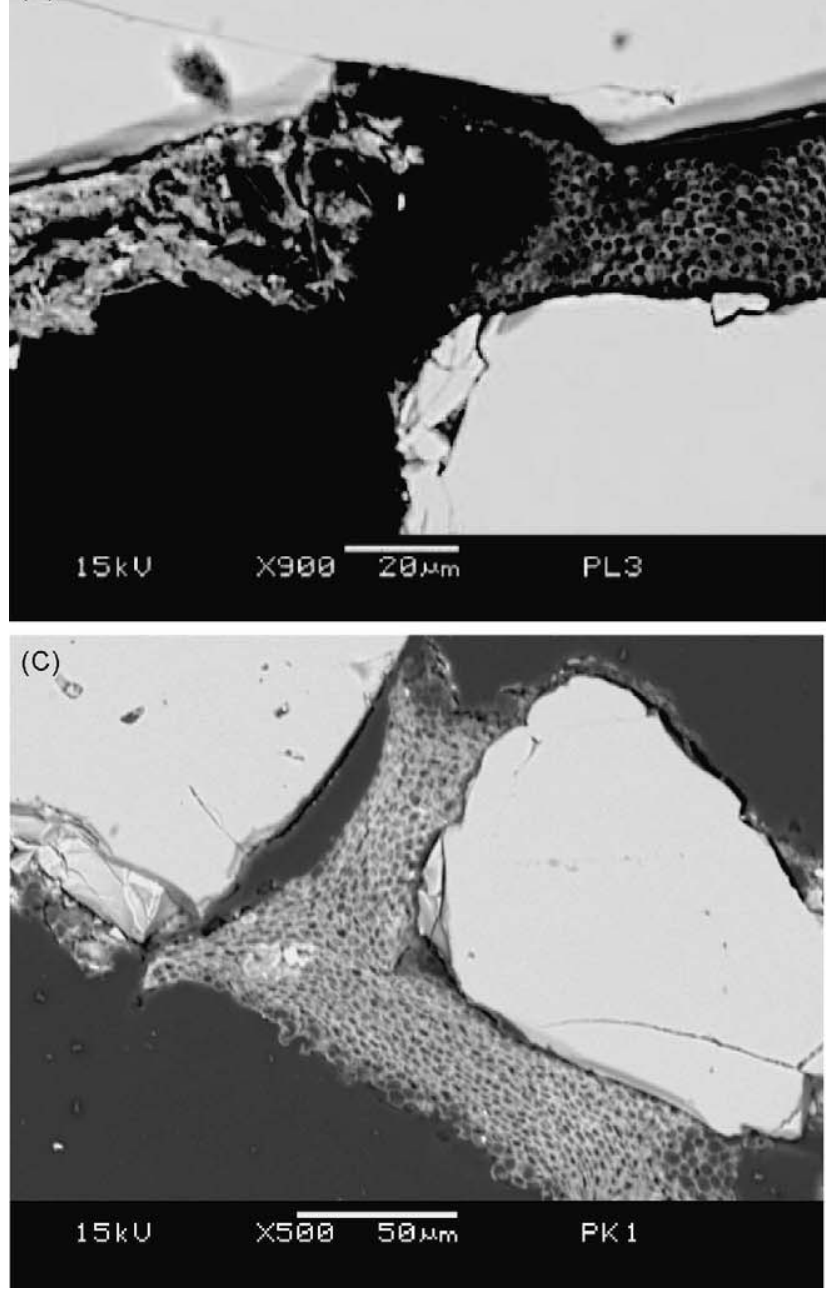

Fig. 9. Representative SEM micrographs of the structure of the cements of Sabellaria alveolata (A), Phragmatopoma caudata (B) and Pectinaria koreni (C) (back-scattered electron mode).

and Paraná), the second one São Paulo, Rio de Janeiro and Paraíba populations, and the third one northern population (Rio Grande do Norte and Ceará). Thus P, Ca and Mg content variations in the mineral phase of the cement enables the identification of different populations of $P$. caudata. This result is not in accordance with genetic analysis which shows that all specimens belong to the same population (Drake et al., 2007). Once again, the importance of environmental variations in the nature of the cement has not been well studied yet and might be a premium factor. It should be considered in the future, as polychaete cement may appear as an environmental marker, which potentially could be very useful for palaeo-environmental reconstruction. The discovery of Miocene sabellarian reefs (Garcin and Vachard, 1987) and Oligocene reef-building polychaete worm (Fisher et al., 1989) provide the first unequivocal examples of fossil terrigeneous annelid reefs. The scarcity of fossil sabellarian reefs contrasts with the abundance of gregarious tube-like trace fossils, commonly considered as worm burrows (e.g., Sabellarifex, Skolithos, Terebellina, Tigillites), that occur in Palaeozoic sandstones. This is partly due to the poor preservation potential of these fragile sandy-reefs but mainly reflects the limited attention given to recognising biosedimentological features in shallow water marine sands and sandstones.

\section{Acknowledgments}

We thank J.-L. Devidal and J.-M. Henot (CNRS, UMR 6524 Magmas et Volcans, University of Clermont-Ferrand) for their help in the use of EPMA and SEM, respectively, and Dr A. Panizza (CNPq, Federal University of Ceará, Fortaleza) for her assistance during the sampling periods. We are grateful to Dr B. Caline (TOTAL, Carbonate and Sedimentology Group, Pau) and Dr C. Bonnot-Courtois (CNRS, UMR 8586 PRODIG, École Pratique des Hautes Études, Dinard) for helpful comments and recommendations which improved this paper. We especially thank A. Curd (MNHN) for improving the English of this manuscript. We greatly thank the anonymous reviewer for comments and improvement of the manuscript.

\section{References}

Busch, D.A., Loveland, R.E., 1975. Tube-Worm-Sediment relationships in populations of Pectinaria gouldii (Polychaeta: Pectinariidae) from Barnegat Bay, New Jersey, USA. Marine Biology 33, 255-264.

Caline, B., Gruet, Y., Legendre, C., Le Rhun, J., L'Homer, A., Mathieu, R., Zbinden, R., 1988. Les récifs à Annélides (Hermelles) en Baie du MontSaint-Michel. Écologie, géomorphologie, sédimentologie, implications géologiques. Documents du Bureau de Recherches Géologiques et minières 156, Orléans.

Clark, I., 1965. Relation of magnesium ions to calcium and phosphate absorption. Nature 207, 982.

Clarke, K.R., Gorley, R.N., 2006. User Manual/Tutorial, PRIMER-E. Plymouth.

Clarke, K.R., Warwick, R.M., 1994. Change in Marine Communities: An Approach to Statistical Analysis and Interpretation. Plymouth Marine Laboratory, Plymouth.

Dobbs, F.C., Scholly, T.A., 1986. Sediment processing and selective feeding by Pectinaria koreni (Polychaeta: Pectinariidae). Marine Ecology Progress Series 29, 165-176.

Drake, C., McCarthy, D., Dohlen, C., 2007. Molecular relationships and species divergence among Phragmatopoma spp. (Polychaeta: Sabellariidae) in the Americas. Marine Biology 150, 345-358.

Dubois, S., Barillé, L., Retière, C., 2003. Efficiency of particle retention and clearance rate in the polychaete Sabellaria alveolata L. Comptes Rendus Biologies 326, 413-421. 
Dubois, S., Retière, C., Olivier, F., 2002. Biodiversity associated with Sabellaria alveolata (Polychaeta: Sabellariidae) reefs: effects of human disturbances. Journal of the Marine Biological Association of the United Kingdom 82, 817-826.

Farcy, S., 2003. Analyse de la structure génétique des récifs de Sabellaria alveolata (L.) dans la baie du Mont-Saint-Michel à l'aide de marqueurs microsatellites. Msc, université Pierre-et-Marie-Curie, Paris VI.

Féral, P., 1989. Influence des populations de Lanice conchilega (Pallas) (annélide polychète) sur la sédimentation sableuse intertidale de deux plages bas-normandes (France). Bulletin de la Société géologique de France 6, 1193-1200.

Field, J.G., Clarke, K.R., Warwick, R.M., 1982. A practical strategy for analyzing multispecies distributions patterns. Marine Ecology Progress Series 8, 37-52.

Fisher, R., Galli, O.C., Reitner, J., 1989. Skeletal structure, growth, and palaeoecology of the patch reef-building polychaete worm Diplochaetes mexicanus Wilson, 1986 from the Oligocene of Baja California (Mexico). Geobios 22, 761-775.

Flammang, P., Lambert, A., 2008. Cement ultrastructure and adhesive glands morphology in the tube-dwelling polychaete Sabellaria alveolata. Journal of Morphology 269, 1479-11479.

Fournier, J., Etienne, S., Caline, B., Le Vot, M., Panizza, A., Devidal, J.L., Lasnel, R., 2007a. Sedimentary characteristics of intertidal worm reefs constructed by Sabellariid Phragmatopoma caudata (Krøyer) Mörch, 1863 along the Brazilian coast. 11ème Congrès Français de Sédimentologie, Publications de l'ASF 57, Caen.

Fournier, J., Olivier, F., Toupoint, N., Godet, L., Le Vot, M., Caline, B., $2007 \mathrm{~b}$. Signature morpho-sédimentaire des biohermes à Lanice conchilega (Pallas, 1766) de la Baie du Mont-Saint-Michel. $11^{\mathrm{e}}$ Congrès Français de Sédimentologie, Publication de l'ASF 57, Caen.

Fournier, J., Panizza, A., Etienne, S., Lana, P.C., Le Vot, M., 2005. Biogeomorphology of Phragmatopoma lapidosa Kinberg, 1867 reefs formations of São Paulo State rocky coasts (Brazil). In: 6th International Conference on Geomorphology: Geomorphology in regions of environmental contrasts, Abstracts volume, Universidad de Zaragoza.

Garcin, M., Vachard, D., 1987. Découverte d'hermelles fossiles dans le Messinien de San Miguel de Salinas (Annélides du Miocène supérieur du Sud-Est de l'Espagne). Geobios 20, 407-414.

Godet, L., Toupoint, N., Fournier, J., Le Mao, P., Retière, C., Olivier, F., 2009. Clam farmers and oystercatchers: effects of the degradation of Lanice conchilega beds by shellfish farming on the spatial distribution of shorebirds. Marine Pollution Bulletin 58, 589-595.

Godet, L., Toupoint, N., Olivier, F., Fournier, J., Retière, C., 2008. Considering the functional value of common marine species as a conservation stake: the case of sandmason worm Lanice conchilega (Pallas, 1766) (Annelida, Polychaeta) beds. Ambio 37, 347-355.

Gruet, Y., Vovelle, J., Grasset, M., 1987. Biomineral components of tube cement of Sabellaria alveolata (L.) (Annelida, Polychaeta). Canadian Journal of Zoology 65, 837-842.

Jensen, R.A., Morse, D.E., 1988. The bioadhesive of Phragmatopoma californica tubes - a silk-like cement containing L-Dopa, Journal of Comparative Physiology B Biochemical. Systemic and Environmental Physiology $158,317-324$.

Kirtley, D.W., 1994. A Review and Taxonomic Revision of the Family Sabellariidae Johnston, 1865 (Annelida; Polychaeta). Sabecon Press, Science Series, Florida.

Kirtley, D.W., Tanner, W.F., 1968. Sabellariid worms: builders of a major reef type. Journal of Sedimentary Petrology 38, 73-78.

Lafon, M., 1959. Recherches sur les tubes de deux Polychètes sédentaires. Archives de Zoologie Expérimentale et Générale 96, 90-102.

Legendre, P., Legendre, L., 1998. Numerical Ecology. Elsevier, New-York.

Main, M.B., Nelson, W.G., 1988. Sedimentary characteristics of Sabellariid worm reefs (Phragmatopoma lapidosa Kinberg). Estuarine, Coastal and Shelf Science 26, 105-109.

Murray, J.M.H., Meadows, A., Meadows, P.S., 2002. Biogeomorphological implications of microscale interactions between sediment geotechnics and marine benthos: a review. Geomorphology 47, 15-30.
Naylor, L.A., Viles, H.A., 2000. A temperate reef builder: an evaluation of the growth, morphology and composition of Sabellaria alveolata (L.) colonies on carbonate platforms in South Wales. In: Insalaco, E., Skelton, P.W., Palmer, T.J. (Eds.), Carbonate Platform Systems: Components and Interactions. Geological Society, Special Publications 178, London, pp. 9-19.

Nichols, F.H., 1974. Sediment turnover by a deposit-feeding polychaete. Limnology and Oceanography 19, 945-950.

Rabaut, M., Guilini, K., Van Hoey, G., Vincx, M., Degraer, S., 2007. A bioengineered soft-bottom environment: The impact of Lanice conchilega on the benthic species-specific densities and community structure. Estuarine, Coastal and Shelf Science 75, 525-536.

Rabaut, M., Vincx, M., Degraer, S., 2008. Do Lanice conchilega (sandmason) aggregations classify as reefs? Quantifying habitat modifying effects. Helgoland Marine Research 63, 37-46.

Rigal, F., 2005. Barrières biogéographiques et processus historiques chez les invertébrés marins : définition des unités taxonomiques et populationnelles chez Sabellaria alveolata. Msc Science, Université de Paris XI, Orsay.

Reise, K., 2002. Sediment mediated species interactions in coastal waters. Journal of Sea Research 48, 127-141.

Scherrer, B., 1984. Biostatistique. Éditions G. Morin. Boucherville, Québec.

Simkiss, K., 1983. Trace elements as probes of biomineralization. In: Westbroek, P., Dejong, E.W. (Eds.), Biomineralization and Biological Metal Accumulation. D. Reidel Publishing Co, Dordrecht, pp. 363-371.

Shao, H., Bachus, K.N., Stewart, R.J., 2009. A water-borne adhesive modeled after the sandcastle glue of $P$. californica. Macromolecular Bioscience 9, 464-471.

Stevens, M.J., Steren, R.E., Hlady, V., Stewart, R.J., 2007. Multiscale structure of the underwater adhesive of Phragmatopoma californica: a nanostructured latex with a steep microporosity gradient. Langmuir 23, 5045-5049.

Stewart, R.J., Weaver, J.C., Morse, D.E., Waite, J.H., 2004. The tube cement of Phragmatopoma californica: a solid foam. Journal of Experimental Biology 207, 4727-4734.

Strasser, M., Pieloth, U., 2001. Recolonization pattern of the polychaete Lanice conchilega on an intertidal sand flat following the severe winter of 1995/ 1996. Helgoland Marine Research 55, 176-181.

Sun, C., Fanter, G.E., Adams, J., Hansma, P.K., Waite, J.H., 2007. The role of calcium and magnesium in the concrete tubes of the sandcastle worm. Journal of Experimental Biology 210, 1481-1488.

Toupoint, N., Godet, L., Fournier, J., Retière, C., Olivier, F., 2008. Does manila Clam cultivation affect habitats of the engineer species Lanice conchilega (Pallas, 1766)? Marine Pollution Bulletin 56, 1429-1438.

Truchet, M., Vovelle, J., 1977. Étude de la glande cémentaire d'un Polychète tubicole, Pectinaria (=Lagis) koreni, à l'aide de la microsonde électronique, du microanalyseur par émission ionique secondaire, et du microscope électronique à balayage. Calcification Tissue Research 24, 231-238.

Vovelle, J., 1965. Le tube de Sabellaria alveolata (L.) Annélide Polychète Hermillidae et son ciment. Étude écologique, expérimentale, histologique, et histochimique. Archives de Zoologie Expérimentale et Générale 106, 1-187.

Vovelle, J., 1973. Évolution de la taille des grains du tube arénacé en fonction de la croissance chez Pectinaria (Lagis) koreni Malmgren (Polychète sédentaire). Ophelia 10, 169-184.

Vovelle, J., Grasset, M., 1990. New data about the forming and composition of the larval tube of Pectinaria (=Lagis) koreni Malmgren (Annelida, Polychaeta). Cahiers de Biologie Marine 31, 333-348.

Waite, J.H., 1987. Nature's underwater adhesive specialist. International Journal of Adhesion and Adhesives 7, 9-14.

Waite, J.H., Jensen, R.A., Morse, D.E., 1992. Cement precursor proteins of the reef-building polychaete Phragmatopoma californica (Fewkes). Biochemistry (American Chemical Society) 31, 5733-5738.

Zar, J.H., 1999. Biostatistical Analysis. Fourth Edition. Upper Saddle River. Prentice Hall, New Jersey.

Zhao, H., Sun, C., Stewart, R.J., Waite, J.H., 2005. Cement proteins of the tubebuilding Polychaete Phragmatopoma californica. Journal of Biological Chemistry 280, 42938-42944.

Zühlke, R., 2001. Polychaete tubes create ephemeral community patterns: Lanice conchilega (Pallas, 1766) associations studied over six years. Journal of Sea Research 46, 261-272. 